\title{
Retraction Note: Artificial intelligence-based water and soil erosion around cities and spatial distribution of sports public service resources
}

\author{
Fan $\mathrm{He}^{1}$
}

Published online: 3 November 2021

C) Saudi Society for Geosciences 2021

Retraction Note: Arabian Journal of Geosciences (2021) 14: 1252

https://doi.org/10.1007/s12517-021-07363-1

The Editor-in-Chief and the Publisher have retracted this article because the content of this article is nonsensical. The peer review process was not carried out in accordance with the Publisher's peer review policy. The author does not agree to this retraction.

The original article can be found online at https://doi.org/10.1007/ s12517-021-07363-1

\section{Fan $\mathrm{He}$}

hefan9588@163.com

1 Department of Public Education, Anhui Finance \& Trade Vocational College, Hefei 230601, China 